\title{
Politicized Discourses
}

A Reflexive Approach to the Transnational Campaign on Women, Peace and Security and its Local Narratives

María Martín de Almagro Iniesta

\section{OpenEdition}

\section{Journals}

Electronic version

URL: http://journals.openedition.org/anthropodev/509

DOI: 10.4000/anthropodev.509

ISSN: 2553-1719

\section{Publisher}

APAD - Association pour l'anthropologie du changement social et du développement

\section{Printed version}

Date of publication: 1 July 2016

Number of pages: 101-122

ISBN: 797-10-93476-03-2

ISSN: 2276-2019

Electronic reference

María Martín de Almagro Iniesta, «Politicized Discourses », Anthropologie \& développement [Online], 44 | 2016, Online since 01 January 2017, connection on 19 April 2019. URL : http:// journals.openedition.org/anthropodev/509 ; DOI : 10.4000/anthropodev.509

La revue Anthropologie \& développement est mise à disposition selon les termes de la Licence Creative Commons Attribution 4.0 International. 


\section{Politicized Discourses}

\section{A Reflexive Approach to the Transnational Campaign on Women, Peace and Security and its Local Narratives}

María Martín de Almagro Iniesta

Cet article théorise un processus de recherche sur la campagne transnationale de plaidoyer pour la mise en place de la résolution UNSCR 1325 sur les Femmes, la Paix et la Sécurité au Burundi et au Libéria. Au début de mes recherches, je partageais le point de vue d'une bonne partie de l'élite politique et des activistes sur la nécessité d'un plaidoyer pour l'introduction de quotas garantissant la présence de femmes dans les listes électorales. Mais, au fur et à mesure que j'avais accès aux discours de résistance infrapolitique des groupements locaux de femmes (Scott, 1990), j'ai ressenti une gêne croissante à l'égard de cette mesure censée améliorer la situation sécuritaire des femmes dans des pays post-conflit. Je suggère que l'analyse de cette gêne apporte des pistes épistémologiques essentielles sur les politiques de domination du discours qui caractérisent le champ du politique et qui résultent en une complicité et un soutien dans la sphère publique des normes dominantes par une majorité d'acteurs. Une approche réflexive de l'étude des mouvements sociaux $m^{\prime} a$ permis de dépasser le jugement implicite dans la littérature qui détermine que, dans une campagne internationale de plaidoyer, le contestataire et le contesté sont deux entités sociales distinctes et unifiées avec des récits stables et convergents.

This article problematizes the research process on the transnational campaign in Burundi and Liberia for the implementation of UNSCR 1325 on Women, Peace and Security. In this process, I began to relinquish the position I had previously shared, as a feminist scholar and activist, 
with the political elite and the advocacy network on the need for an "affirmative action model" and the introduction of quotas for women in government. My increasing discomfort with that position is analyzed to provide essential epistemic insight into the politics of discourse domination, the so-called public transcript (Scott, 1990) that characterizes the wider policy field. A reflexive approach to the study of social movements is adopted to overcome the implicit judgment in literature on the subject that, in an advocacy campaign, the contester and the contested are two distinct but unified social entities with stable and congruent narratives. The intention is to provide an account of the complex dyna-mics of fieldwork, wherein the researcher's emotional responses can easily be directed towards the power politics of the advocacy campaign process and, consequently, her own psycho-social world may contain precious data.

Introduction

"Every theory is the fragment of an autobiography" (P. Valéry, in Dauphine, 2013: 358)

This paper explores the role of reflexivity from a post-structuralist perspective, using it as a critical methodological tool and crossreferencing it with arguments concerning representation and legitimization in qualitative research. This includes a detailed analysis of how reflexivity can provide the researcher with new data. Reflexivity - the ability to analyze and understand the power relations operating between the researcher and the object of research - has begun to play a major role in qualitative research methods. It requires researchers to self-examine their interaction, negotiation and transformation of the intersubjective elements of their research. It is used by feminist, post-colonial and poststructural scholars to expose the politics of representation, to better represent "difference" (Wasserfall, 1997), to create a sense of "ethnographic authority" (Britzman, 1995: 229) and simply to legitimize or question their data (Pillow, 2003). For some, it has constituted a way of monitoring the qualitative research process 
and making it transparent, to achieve what is thought to be a more accountable and objective outcome. Nevertheless, it is rare to find studies that specify how reflexivity is being used, as if it were already perceived as a standard, commonly-used methodological practice for critical qualitative research.

Finlay (2002) distinguishes between four types of reflexivity: reflexivity as introspection, reflexivity as intersubjective reflection, reflexivity as social critique and reflexivity as discursive deconstruction. The last two types are favored by post-modernists and constructivists, whereas sociologists used the first two as an introspection of their own research. From a feminist perspective, and based on the argument that my own research is inherently political, I use reflexivity as a powerful "discourse deconstruction" tool that provides me with a variety of data for understanding the intra-network dynamics of transnational advocacy campaigning.

This article analyzes the critical reflexive approach that I adopted du-ring my doctoral research process, on a challenging topic concerning the relationship between the researcher and a specific policy field: global feminist activism. The last decade has witnessed the expansion of a transnational advocacy campaign to create and implement United Nations

Security Council Resolution 1325 (UNSCR 1325) on Women, Peace and Security. The campaign has been highly influential and mediatized. It is underpinned by two key arguments: firstly, that gender issues must be securitized in order to end violence against women in conflict and post-conflict settings and, secondly, that increasing the number of women in decision-making positions will end this violence and create more women-friendly policies. My research focused on the intra-network dynamics of this transnational advocacy campaign, i.e. how transnational activists coalesced with local activists to develop a common discourse to help decision-makers implement UNSCR 1325. Consequently, this article problematizes both of the key arguments and critiques the campaign's policy proposals. It also illustrates how, in this process, I, 
as a researcher, adopted then relinquished the dominant feminist position.

This paper reflects my discomfort at recognizing my contradictory reactions to the affirmative action model for the securitization of women's rights, proposed by the Transnational Advocacy Network on Women, Peace and Security. The model resulted in marginalized women's groups being confronted by resistance of two sorts: ignorance and obstruction. Therefore, this work initially refers to Wanda Pillow's (2003) reflexivities of discomfort, for guidance through the silence and incoherence of accepting a diversity of "truths", and subsequently draws on Linda Finlay's (2002) validation of post-modernist reflexivity variants, as discursive deconstruction and social critique. It is argued that my own discomfort has indeed provided valuable data, by helping me to navigate the politics of discourse creation, validation and domination that characterize the formation of collective action. Using reflexivity in this manner has enabled me to understand my contingent positionality as an activist and a researcher. This positionality reflects the contingent world of global feminist activism and its relationship with securitization politics.

The article is divided into three sections. The first part discusses the concept of reflexivity in the qualitative research process. It argues that researchers can find a good critical resource in the reflexivity of discomfort (Pillow, 2003). It then goes on to extend the concept beyond the identities of the researcher/researched proposed by Pillow, and combine it with the discursive deconstruction variant proposed by Finlay. The intention is to explore the value of reflexivity through gaining access to private and marginalized transcripts during fieldwork. The second part describes my research, beginning with my base-line exploratory work in Burundi, during three one-month stays between 2012 and 2013, and in Liberia, during a three-month stay in 2013. It then discusses my more recent attempts to analyze the relationship between affirmative action discourses, securitization of women's rights and the transnationalisation of women's struggles. On this subject, my increasing discomfort with my position as an activist is noted and 
the reflexive process developed herein described. It is argued that this discomfort helped me to overcome the implicit judgment contained in both literature on the subject and my case study that, in an advocacy campaign, the contester and the contested are two distinct but unified social entities with stable and congruent narratives. In the final section, with the benefit of hindsight, the article analyses how I used reflexivity as a source of data.

\section{The Discomforting "Truths" of Reflexivity}

Reflexivity has become an important methodological and epistemological tool for social science qualitative researchers, who argue that the truth cannot be known as such, but that "truths" are discursively produced, as we are not neutral observers of the world. One of the main trends has been to use personal reflexivity in the research process to understand how who the researcher is, who the researcher has been, who the researcher thinks she is and how she feels affects data collection and analysis (Hesse-Biber and Leavy, 2006: 146). This implies accepting and recognizing that "how knowledge is acquired, organized, and interpreted is relevant to what the claims are" (Altheide and Johnson, 1998). This philosophy, which is influenced by post-modern theory, has posed further questions about a researcher's ability to represent or know another, and about the construction of our ethnographic and qualitative texts. Can we truly represent another? Should research even aim to do so? To whom does the story belong? How do we deal with the contingency of truth? How do we handle representation when we are aware that it is almost impossible to get it right? The reflection and discussion of these questions is now often a part of the qualitative research process and researchers who engage in asking these questions use reflexivity to illustrate how they represent, in order to demonstrate the validity of their work on the politics of representation (Britzman, 1995; Fine, 1994; Lather, 1993, 1995). Reflexivity provides a way to monitor the qualitative research process and make it transparent. As such, personal experience is transformed into accountable knowledge, probably as a response to 
what was thought to be a more objective quantitative analysis in the social sciences.

Critics of reflexivity argued that social sciences should no longer be treated as exact sciences. They considered the proliferation of reflexivity as self-indulgent and narcissistic, and claimed it undermined the necessary conditions for emancipatory research (Kemmis, 1995; Patai, 1994). They questioned whether selfreflexivity could produce better research. However, others, such as Chiseri-Strater, retaliated by distinguishing between reflexivity and reflection:

"To be reflective does not demand an 'other', whereas to be refle-xive demands both an 'other' and some self-conscious awareness of the process of self-scrutiny" (Chiseri-Strater, 1996: 130).

Most current feminist (see, for example, Wilkinson, 1988; Reinharz, 1992; Wibben, 2010) and post-structuralist research uses reflexivity with precisely that intention: to deal with power imbalances between the researcher and the participant and to produce less distorted accounts of the social world (Hertz, 1997). If, based on a post-structuralist and feminist methodology, we accept that reality and the truth are socially created and that subjects are decentralized, then how should we deal with the "truth" that we, as researchers, produce?

It is not possible for us to extract ourselves from the stories we tell; we see them through our own eyes, nuanced by our preconceptions, prejudices and perspectives. Even after we complete the fieldwork, our stories remain with us and continue to affect us. Moreover, how do we deal with the policy practices created as a result of that "truth"? Although in principle, the researcher should be able to write non-ideological discourses, in reality, things are much more complicated. Therefore, reflexivity is used to explicitly convey the impact of intersubjective elements on data collection and analysis, in an attempt to increase legitimacy and transparency. Subjectivity is transformed from a burden into an opportunity (Finlay, 2002). And Pillow (2003) argues that reflexivity 
will serve us better if, instead of using it as methodological justification for qualitative research, the researcher uses it as a methodological tool to interrupt traditional data gathering practices - which she likens to gathering "truths" into boxes, rejecting those ones that do not fit, are unfamiliar and therefore troubling - and turn them into practices which "interrogate the truthfulness of the tale and provide multiple answers" (Trinh, 1991 in Pillow, 2003: 12). Thus, in order for reflexivity to become an opportunity rather than a burden, it must allow room for the discomforting, the unfamiliar and the complexity of the research process. The focus must be placed "on the diverse and shifting positions mutually adopted" (Finlay, 2002: 226).

Accordingly, this article attempts to document the contingent process of inner conflict between myself as an activist, trying to gather data as "truths" or even a "truth", and myself as a feminist researcher, trying to empower marginalized groups and promote their perspectives. This article traces my journey from complicity, as a truth activist, to resistance, taking up the call of Pillow, who argued that:

"The qualitative research arena would benefit from more 'messy' examples, which may not always be successful and do not seek a comfortable, transcendent end-point, but leave us in the uncomfortable realities of doing engaged qualitative research" (Pillow, 2003: 193).

The discursive deconstruction method of reflexivity (Finlay, 2002) is used to argue that the researcher's emotions can be directed towards the power politics of discourse and knowledge creation. It therefore provides a critique, by deconstructing the evolution of my own understanding on the discourse of "gender security". As I became more familiar with existing research and activism in the field of securitization and women's rights in postconflict contexts, the multiplicity of experiences and discourses of "gender security" became striking.

As previously indicated, feminist and post-structuralist research concerns itself greatly with ensuring that it is not abusive of 
research participants and that it is useful and empowering to women. My initial empirical approach was to interview issue entrepreneurs from the transnational advocacy network coalition, the leading NGOs in the campaign, who were engaged in advocating future policy options at a global governance level. However, a power dynamic gradually emerged, whereby I, as the researcher, was leaning towards these issue entrepreneur activists, who were disseminating what had become the dominant discourse on "gender security". The more research I conducted, the more insight I gained into the exclusion of other activists' voices, and how certain "truths" were being shaped both inside the advocacy network and in my own research. The aim of this article is not to arrive at my final interpretation of "gender security" or a common definition for all, but to explain how the discomfort I experienced while researching in the field deepened my analysis and eventually led me to argue that, in an advocacy campaign, the contester and the contested are not two distinct social entities.

Researching the Campaign for the Implementation of UNSCR 1325 in Post-Conflict Burundi and Liberia

I have been working on the intra-network dynamics of feminist trans-national advocacy networks since 2011, with four fieldwork visits to Burundi and Liberia in 2012 and 2013. More specifically, I have been studying the transnational advocacy campaign for the creation of UNSCR 1325 on Women, Peace and Security and the subsequent transnational movements for its implementation in Burundi and Liberia. My objective was to research whether and how the "boomerang effect" (Keck and Sikkink, 1998) - whereby international actors can help local activists by providing them with material and human resources and placing pressure on the national government to pass or not to pass a certain law - had resulted in the empowerment of local women's groups in post-conflict societies.

I believe that interviewees' perception of academics deeply influences the way they represent themselves discursively. 
Accordingly, it should be assumed that my identity as a young female PhD student shaped the way that the interviewees answered my questions in two ways. Firstly, based on the idea the interviewee had of me, as one of the:

\begin{abstract}
"young PhD candidates from good American and European universities running around eagerly in this remote and traumatized country to advance their academic careers interviewing, measuring and theorizing, while surrounded by some of the world's most extreme poverty and gross human rights violations" (Uvin, 2001: 76).
\end{abstract}

Secondly, based on the impression with which the interviewee wanted me to return home. Since, the majority of my interviewees were founders or members of local associations funded by international nongovern-mental organizations (INGOs) or international organizations (IOs) and embassies, it was not surprising that the international schemes and buzzwords for access to funding were omnipresent during the interviews. A high number of interviewees were eager to leave me, as a Westerner, with the impression that their association was performing well.

After an initial exploratory fieldtrip in June 2012, I developed a sche-dule of questions to guide qualitative semi-structured interviews with representatives of NGOs, local women's associations and UN agencies which, at that time, were forging the implementation campaign for 1325 in Burundi and in Liberia. The second round of interviews took place in December 2012, April 2013 and July-September 2013. Guided by the UNSCR 1325, I asked interviewees to identify what "gender security" meant to them, what constituted insecurity and which measures could be implemented to deal with those insecurities. The first stages of data gathering were frustrating, due to the emergence of significant discrepancies in the definitions arising from their varying ideological, cultural and geographical positions. At that point in time, the advocacy coalition's discourse on affirmative action as a means of improving gender security contrasted dramatically with local associations' claims: there had been no improvement in women's security conditions as a result of women being elected. 
Several civil society groups, wedded to the position that gender security is asso-ciated with civil and political rights, argued that gender insecurity is clearly linked to sexual and domestic violence, and that it can be solved by gran-ting females more civil and political rights. A minority of voices shared this view, but argued that socioeconomic conditions were a major source of insecurity and that, in order to achieve gender security, major structural reforms must take place, allowing women the right to inherit and own (Martín de Almagro, 2014). Essentially, there was no common feminist discourse on "gender security" but rather, throughout 10 years of campaigning, the different conceptualizations of "gender security" have affected the master frame, and the strategies chosen by individual groups inside the network have produced a range of policy solutions that do not always suit all campaign stakeholders (Martín de Almagro, 2015).

The outcome of these interviews and experiences was the realization that I must confront the emerging duality of civil and political versus socioeconomic rights; I had become aware that it was having an impact on my interviewees' understanding of the kind of policies that should be implemented to comply with UNSCR 1325. My feminist inclinations about the importance of women's agency led me to support demands for women's civil and political rights. Yet, I was also aware that access to power is gendered. I was concerned that if women activists were to campaign too hard to win socioeconomic rights for women, the governmental authorities would react by pushing for the retraditionalization of society. The aftermath of the Arab Spring has provided various examples of the negative effects of such retraditionalization movements on women and their rights (Johannson-Nogues, 2013). I was puzzled to discover that the unifying agent I had been looking for - the transnational advocacy campaign - did not actually exist. Using reflexive thinking and informed by the work of Laura Shepherd (2008) and others, I began to elaborate a more nuanced response to the dilemmas involved in researching discourse domination in advocacy coalitions. 


\section{Reflecting on Gender Security (-ies)}

The promotion of gender security - including through the introduction of gender quotas - has become a key part of international democracy promotion in post-conflict societies. The UNSCR 1325 framework is expli-citly designed to operate within the mechanisms of the UN, and this is reflected in the language and strategies that it employs. It is one of the strongholds of the liberal, peacebuilding approach promoted by the UN. Its provisions state, firstly, that women should participate at all levels of decisionmaking in conflict resolution and peace processes, secondly, that all actors involved in the peace process should support local women's peace initiatives and, thirdly, that women should be protected from gender-based violence in situations of armed conflict. In the last decade, the international legitimacy of gender quotas has led to their adoption via two causal pathways in post-conflict societies: directly, through post-conflict peace operations, and indirectly, by encouraging countries - especially those dependent on foreign aid to signal their commitment to democracy by adopting quotas (Bush, 2011).

Moreover, ties to the world polity are often measured by the existence of INGOs, which diffuse and promote human rights principles globally (Keck and Sikkink, 1998). In our case, these ties can be represented through women's INGOs, which are particularly significant for quota adoption, as they provide organizational and informational resources for domestic activists (True and Minstrom, 2001). When organizing a common advocacy campaign, strong commitment to a joint vision is an important unifying tool. In the area I was researching, the common goal seemed clear: stopping sexual and gender-based violence in post-conflict countries and saving women. Initially, the common discourse master frame for achieving this appeared well-defined to me. But I subsequently found myself rejecting the reductionism of the "empower women to political offices" viewpoint, and criticizing the assumptions contained therein about "gender security" and its relationship with the socioeconomic situation. 
Eventually, I turned to Shepherd and McLeod's work on the multiplicity of discourses on "gender security" to reach an understanding of why the advocacy network had focused on implementing the first part of UNSCR 1325, while overlooking the second, which stipulated that "all actors involved in the peace process should support local women's peace initiatives" (UNSCR 1325, 8(b)). For McLeod (2011: 595), "gender security" is based on the creation of links between discourses of security and discourses of gender. Conceptualizations of both gender and security rely on a particular set of logics (Shepherd, 2010: 5; 2008: 294), logics being "the ways in which various concepts are organized within specific discourses" (Shepherd, 2008: 294). Therefore, the specific logic of "gender security" depends on how concepts such as gender and/or security are rearranged, as well as the "assumptions that inform them and the policy prescriptions that issue from them" (Shepherd, 2008: 94). As McLeod (2011: 595) puts it, there is no single logic regarding what "gender security" might look like, but each vision of "gender security" is underpinned by a set of political considerations governing the way we chose to frame it. Consequently, by tracing the transnational campaign process for the signature and implementation of UNSCR 1325, we can see that the policy translation of UNSCR 1325 has provided opportunities for political action. Actors' behavior is generally assumed to be driven by their perceptions of the world. Therefore, associations and ambivalence as to what constitutes security and peace have an impact on how actors frame an issue - in this case, women's rights in post-conflict settings.

Yet, how has a transnational campaign for the protection of women from violence in conflict and post-conflict situations, and for their em-powerment in post-conflict reconstruction, become an affirmative action campaign for the inclusion of quotas at all levels of government? To ans-wer this question, I immersed myself in a process of reflexive discourse deconstruction, conducting an indepth analysis into the ambiguity of the language used in the internal negotiation dynamics of the transnational advocacy network. I discovered that different security narratives were being 
eroded by the public transcript promoted by a powerful, UN-backed network of NGOs. This network has certainly managed to keep "gender security" on the highest levels of the global agenda, yet it has done so at the expense of different local narratives provided by Burundian and Libe-rian activists.

\section{Burundi: No Inheritance, No Peace; No Peace, No Security}

Burundi is known for its engaged civil society and vibrant independent media. Women's associations in the country are very influential and have a long history of success. Having been excluded from participating in the negotiation process for the Arusha agreement, an All-Party Burundian Women's Peace Conference, convened by UNIFEM and the Mwalimu Nyerere Foundation, took place in parallel to the peace talks, with the aim of drafting a set of recommendations to ensure the Arusha Accords had a gender-sensitive outlook. According to some witnesses, the evolution of the security situation in Burundi and the recommendations of

the Women's Peace Conference were responsible for the adoption of Resolution 1325 by the United Nation Security Council in session 42137, on 31 October 2000.

As a result of this resolution, leaders of the political parties slowly began to appoint women to political posts in the delegations in charge of negotiating the Arusha Peace and Reconciliation Agreement. Women also demanded a 30\% quota for government positions, which they obtained at a national level. As stated, I used to share the dominant perception that, following the 2010 elections, the $46 \%$ female presence in the Burundian Senate and $32 \%$ female presence in the Congress would help place women's priorities at the top of the agenda in state security and decision-making processes. I considered it a success of Keck and Sikkink's boome-rang effect. However, I soon after interviewed some local women's groups, which claimed that quota representation was rooted in an ideological perspective that did not take into consideration the macro-social conditions of the country. 
They explained that without allowing women the rights to inherit and own, it made no sense to make them public political figures. If the power inequalities in Burundian society remained untouched, women would still be victims rather than agents of development. This marked the emergence of a new discourse on "gender security", based on socioeconomic rights, and the launch of a new campaign for women's inheritance rights.

Local women's groups asked for the help of the transnational advocacy network to implement UNSCR 1325 . Yet, in subsequent interviews, it became abundantly clear to me that their perspective on "gender security" was being buried on a transnational scale. Thus, as the national government was demanding an end to the campaign for inheritance rights, and since donors and IOs did not wish to jeopardize their relationship - or that of the international NGOs they fund - with the national government, the response of international NGOs has been to disaggregate both discourses. On the one hand, these organizations carry out advocacy work for elections and gender violence awareness-raising, as part of programs funded by Resolution 1325 implementation funds. On the other hand, they support local partners in the battle for women's socioeconomic rights, as part of the campaign for gender mainstreaming and gender equality in the II Strategic Framework for the Fight Against Poverty in Burundi, a national program created by the Burundian government, which ensures it is limited to the domestic context. This internalization of the campaign is inextricably linked with its de-securitization. Significantly, this came to light following the repeated claims of UNSCR 1325 issue entrepreneurs that it was not the right time to demand socioeconomic security. They argued that doing so could block other campaigns for women's rights and result in the retraditionalization of society ${ }^{1}$ with potentially serious detrimental consequences for "real" gender security issues.

\footnotetext{
${ }^{1}$ Interview with a former staff member at an international NGO in Burundi, Bujumbura, December 2012.
} 
Once again, I felt discouraged: some gender security discourses do not belong in the transnational sphere, whereas others are undoubtedly a matter of international politics and, therefore, international advocacy. Which "gender security" perspectives should I include in my analysis of the transnational campaign on Women, Peace and Security? Should I infer that socioeconomic security based on inheritance rights is part of a different campaign? Should I neglect to mention it, since it has not resulted in the UNSCR 1325 transnational campaign producing a successful boomerang effect? Who is responsible for deciding which gender security objectives form part of the transnational campaign? How should I define this unba-lanced relationship?

\section{Liberia: Pray the Devil Back to Hell but Pray the Women Back Home, too}

With a more open mind to the potentially differing truths on gender security, I travelled to Liberia, the front runner for women's rights, whose women's peace movement achieved international recognition through the film Pray the Devil Back to Hell ${ }^{2}$. This film was the catalyst for the award of the Nobel Peace Prize to the social worker, Leymah Gbowee, and the Pre-sident of Liberia, Ellen Johnson Sirleaf. In this country, which was devasta-ted by two civil wars between 1996 and 2003, the top issue entrepreneurs' associations rely on a clear grassroots mobilization advantage, and go by the name of "ambassadors of peace". My interviews in Liberia, during the summer of 2013, confirmed that the women's organizations operating there have a very similar gender security framework to that of the international activists in the UNSCR 1325 implementation campaign. Security is construed as the absence of physical violence, and insecurity as sexual and domestic violence. At the time of writing, women are organizing a campaign to obtain a $30 \%$ minimum quota for women on the list of candidates submitted

2 Fork Films: http://www.praythedevilbacktohell.com/nonflash/about.htm, 22 October, 2008. 
by political parties for the parliamentary elections ${ }^{3}$ and another campaign against rape. The most important organizations, AFELL, MARWOPNET and WIPNET, do not use security arguments in their advocacy campaigns against the difficult socioeconomic situation of women in the country. In my research, I found no instances of hybridization or amplification of discourse, but rather a clear acceptance of the discursive framework proposed by the northern issue entrepreneurs. Furthermore, al-though the Equity Bill proposing a minimum quota in electoral lists had long been pending approval in Parliament and seemed unlikely to be passed at all, the transnational network was still insisting on advocating it.

As a result, and following the lessons I had learned from Burundi, I could no longer conform to a neat and tidy, unified discourse. I was forced to dig deeper in search of hidden transcripts. Why was the emphasis still being placed on high-level affirmative action, when in other countries statistics have proved that the presence of more women in Parliament does not necessarily improve the security situation for females? Eventually, I discovered activist groups that did not comprise part of the female elite, focusing on gender quotas in the highest instances of decisionmaking. Together with other civil society groups, these women were advocating the reform of the Local Government Act. They were urging women not to forget about their role as "ambassadors of peace", to return home and to take up public roles at a local and community-wide level.

Some of my interviewees claimed that there was a significant gap between the elite few females in the country and the

\footnotetext{
${ }^{3}$ The campaign to draft the Equity Act, as part of the Electoral Reform Law, calling for political parties to implement $30 \%$ minimum quotas for each gender when submitting the names of candidates for an election. According to Section $4.5(1 \mathrm{~A})$ of the proposed Law, "In submitting to the Commission, a list of its candidates for elective office, a political party or coalition should endeavour to ensure that the governing body and its list of candidates has no less than 30 percent of its members from each gender." This campaign was almost completely funded by UNIFEM and by several INGOs.
} 
grassroots. The distance between them could be reduced and their relationship strengthened by pushing for a Local Government Act that would make it easier for women to fill political seats at a regional level. This, in turn, would facilitate the passing of legislation at a communal level, for women's access to economic resources and the creation of local structures for dealing with cases of gender violence. However, these issues have not appeared on any agenda in the international arena. The hegemony of the discourse on phy-sical security is also emphasized by the lack of an organized alternative voice. It is extremely difficult to find an unconventional discourse, with the exception of occasional comments from one or two local organizations specializing in socioeconomic affairs. These organizations are also highly critical of the monopoly exercised by the Rural Women's Network on discourses of a socioeconomic nature. This network, founded and run by the Ministry of Gender and Development of Liberia, centralizes and distributes national and international funding for female rural groupings. The Ministry decides which rural organizations meet the criteria to be a member of the Network and, therefore, which organizations benefit from its funding and resources. The international network of activists seems to ignore any obstruction by governmental bodies of the rural women's groupings that do not belong to their network (Dessbucher and Martín de Almagro, 2016).

As a critical feminist researcher of social movements, I was obligated to take seriously the accounts given by local women's associations, if only to problematize the growing belief in postconflict societies, and globally, that affirmative action is a means of achieving gender security. I was disturbed at how victimhood and the representation crisis had seamlessly made their way into the public transcript underpinning the growing coalition to adopt national measures to implement UNSCR 1325. My analysis of the substantive issues at stake here was aided by the work of Shepherd (2008) and McLeod $(2011,2013)$ on gender security discourses and by the social movements' theorists Heins (2008) and Bob (2005). Like Shepherd and McLeod, I found that official public transcripts of 
gender security left me little room to articulate my discomfort or to problematize the hegemonic perspective, and risked my exclusion as a researcher from the "feminist" category.

My experience as researcher in the field of "gender security" was uncomfortable. I found it awkward to identify my position in a contested public sphere, and I experienced contingent feelings based on my differing positions as a feminist and as a researcher. Reflexivity has proven itself to be an evolving method that has enabled me to develop both scholarly criticism of dominant discourse and insider knowledge in the field.

The final section of this article details exactly how reflexivity can promote critical knowledge and provide new data.

\section{Using Reflexivity as a Source of Data: the Power Politics of the Policy-Making Process}

Conducting research in post-conflict environments can be a particularly challenging and delicate subject for academics, as the politics surrounding it are contentious and emotive. Feminist scholars are supposed to advocate empowerment and societal transformation. So how should they react when their feminist research and action becomes irreconcilable with what they once considered as the only possible position for a feminist activist to adopt?

Although this article has been written in a linear fashion for the sake of clarity, the reality of the research process was messy. The objective was not to systematize my research but rather to reflect on how my emotional self - including my personal ties to the women's movement and its goals, my identity as a feminist researcher and activist, and the relationships I developed with the campaign's issue entrepreneurs - reached an understanding of how a single formulation of "gender security", decided at a global level, comes to determine which policies are valid, at what moment, and where. Gaining access to other, marginalized voices, which had 
been denied access to the transnational campaign and were therefore not a part of the public transcript, presented a challenge. It took me time to acquire an understanding of the complexity of conducting field research, and to realize why it was so challenging: my own voice and research was shaped by the diverse temporal, geographical and cultural dimensions of knowledge creation and intersubjectivity. Accordingly, reflexive contemplation explicitly conveyed the ways in which "truths" can be determined by activistdriven research, which a priori precludes opposing views.

I began to realize that my psychosocial discomfort was revealing of the discourse domination that characterizes global activism and governance. My rejection of the "passive victim" discourse surrounding women in conflict and post-conflict settings compelled me to change my position. Refle-xive discursive reconstruction made this possible. It is clear, from the variety of experiences I encountered during my empirical research on the Women, Peace and Security network and on the Burundian and Liberian scene, that the world cannot be known in its entirety, especially not through a single transnational campaign (Pillow, 2003). Therefore, my position became contingent rather than permanent. However, I found it challenging, as a feminist and a scholar, to articulate this contingency in the face of a science that requires certainty, and a discipline of social movement studies that documents successes rather than failures.

Despite my discomfort at the dissenting voices, I knew they were telling me something about how public transnational activist discourses were being shaped. Listening to them helped me to understand the power politics of advocacy network creation and knowledge production as closely resembling the more institutionalized structures of global decision-making. These voices guided me from my initial uncertainty and denial of complexity, to the research finding that there is a power structure favoring a singular discourse on "gender security", which overshadows other voices. As Butler put it: 
"The task of the postcolonial translator... is precisely to bring into relief the non-convergence of discourses so that one might know through the very ruptures of narrativity as the founding violence of the episteme" (Butler, 2000: 37).

My own research on transnational advocacy and much of the literature on social movements agree on the importance of a common discourse, common values and a common strategy (Keck and Sikkink, 1998) to the success of a campaign. It is essential to remember that while conducting a long research process, one is also guided by certain values and viewpoints. It was only by using a methodology based on reflexivities of discomfort that I was able to explain where all these contingent approaches came from and to establish the interconnection between global activism, gender policies and the gendered dimension of neo-liberal security regimes.

The lesson I have taken from this reflexivity process is that the scholars who depict horizontal networking and a shared identity as women activists and as a constant feature in transnational advocacy are failing to observe changes or amplifications in the advocacy campaign's master frame over time, and how it is changing the rules of the game. The dominant logic of "gender security" that has arisen from the post-conflict configuration as an external issue suggests that women can be secured through equalizing opportunities, and that if women are formal political actors they will be secured. The efforts of international actors to implement UNSCR 1325 may reinforce perceptions of women's gender roles, perpetuating the separation of the public/private spheres of influence and subjugation. The politicization of women's roles during and after conflict would require women's activities in the household and in public spaces to be intricately intertwined. With few exceptions, women's participation in post-conflict reconstruction is rarely construed as a political role, whereas strategies geared towards women's resilience and survival are seen as natural extensions of their natures during and after conflicts (El Bushra, 2007). Consequently, practical solutions to gender inequities emphasize institutional me-chanisms (UNSCR 1325; 
gender quotas) to entrench women's rights but disregard the household dynamics that are often sustained by patriarchal attitudes (Shepherd, 2008; El Bushra and Mukarubuga, 1995) and promo-ted by a liberal peace conception. The key activist in the coalition for women's rights proved to wield the most power in maintaining the status quo: the international norm entrepreneurs and their concept of "gender security" did not provide new space and time for renegotiation.

A reflexive critical approach was particularly useful to me. It provided me, as a researcher, with an opportunity to reflect on the continuous cons-truction of meaning through discourse, and on how identity and power are politically created and transformed (see also Foucault, 1982). I believe that good qualitative academic research should incorporate reflexivity to account for multiplicity: to acknowledge that there are parts of the truth we cannot know and that not everything can be clearly labelled and pigeonholed. The reflexivity of discomfort proposed by Pillow will help resear-chers to convey complexity in the face of a simplified consensus. In my case, the reflexive process allowed me to recognize, if not reconcile, the stark contrast between the real concerns of a large community of local activists, the current public transcripts defining "gender security" and the action that the global community should take in order to achieve it.

\section{References}

ALTHEIDE D. and JOHNSON J., 1998, "Criteria for assessing interpretive validity in qualitative research", in DENZIN N. and LINCOLN Y. (eds.), Collecting and interpreting qualitative materials, Thousand Oaks, CA, Sage: 283-312.

BOB C., 2005, The Marketing of Rebellion: Insurgents, Media and International Activism, Cambridge, Cambridge University Press.

BRITZMAN D., 1995, “The question of belief': writing post-structural ethnography", International Journal of Qualitative Studies in Education, 8 (3): 229-238. 
BUTLER J., 2000, "Restaging the Universal", in BUTLER J., LACLAU E. and ZIZEK S., Contingency, Hegemony, Universality, New York, Verso.

BUSH S., 2011, "International Politics and the Spread of Quotas for Women in Legislatures", International Organization, 65: 103-37.

CHISERI-STRATER E., 1996, "Turning in upon ourselves: Positionality, subjectivity, and reflexivity in case study and ethnographic research", in MORTENSEN P. and KIRSCH G.E. (eds.), Ethics and responsibility in qualitative studies of literacy, Urbana, IL, NCTE: 96-113.

DAUPHINE E., 2013, "Writing as hope: Reflections on The Politics of Exile", Security Dialogue, 44: 347-361.

DESSBUCHER P. and MARTIN DE ALMAGRO M. 2016, "Post-conflict women's movements in turmoil: the challenges of success in Liberia in the 2005-aftermath", The Journal of Modern African Studies, 54: 293-316.

EL BUSHRA J. and MUKARUBUGA C., 1995, "Women, War and Transition", Gender and Development, 3 (3): 16-22.

EL BUSHRA J., 2007, "Feminism, Gender and Women's Peace Activism", Development and Change, 38 (1): 131-147.

FINE M., 1994, “Di-stance and other stances: Negotiations of power inside feminist research", in GITLEN A. (ed), Power and method, New York, Routledge: 13-35.

FINLAY L., 2002, "Negotiating the swamp: the opportunity and challenge of reflexivity in research practice", Qualitative Research, 2 (2): 209230.

FOUCAULT M., 1982, "The Subject and Power", Critical Inquiry, 8 (4): 777795.

HEINS V., 2008, Non-Governmental Organizations in International Society: Struggles for Recognition, London, Palgrave Macmillan.

HERZ R. (ed), 1997, Reflexivity and Voice, Thousand Oaks, CA, Sage.

HESSE-BIBER S.N. and LEAVY P., 2006, Emergent methods in social research, Thousand Oaks, CA, Sage. 
JOHANNSON-NOGUES E., 2013, "Gendering the Arab Spring? Rights and (in)security of Tunisian, Egyptian and Libyan women", Security Dialogue, 44: 393-409.

KECK M. and SIKKINK K., 1998, Activists Beyond Borders: Advocacy Networks in International Politics, Ithaca and London, Cornell University Press.

KEMMIS S., 1995, “Action research and communicative action: Changing teaching practices and the organisation of educational work". Paper presented to the National forum of the Innovative Links Project.

LATHER P., 1993, "Fertile obsession: Validity after poststructuralism", Sociological Quarterly, 34 (4): 673-693.

LATHER P., 1995, "The validity of angels: Interpretive and textual strategies in researching the lives of women with HIV/AIDS", Qualitative Inquiry, 1 (1): 41-68.

MARTIN DE ALMAGRO M., 2014, "La desglobalización de la sociedad civil: los casos de Burundi y Liberia sobre los derechos de la mujer", Revista CIDOB d'afers internacionals, 105: 117-140.

MARTIN DE ALMAGRO M., 2015, "Negotiated contestation in peacebuilding: maintaining or transforming systemic narratives?, Critical Studies on Security, 3 (3): 326-327.

MCLEOD L., 2011, "Configurations of Post-Conflict: Impacts of Representations of Conflict and Post-Conflict upon the (Political) Translations of Gender Security within UNSCR 1325", International Feminist Journal of Politics, 13 (4): 594-611.

McLEOD L., 2013, "Back to the future: Temporality and Gender Security Narratives in Serbia", Security Dialogue, 44 (2): 165-181.

PATAI D., 1994, "(Response) When method becomes power", in GITLEN A. (ed), Power and method, New York, Routledge: 61-73.

PILLOW W., 2003, "Confession, catharsis, or cure? Rethinking the uses of reflexivity as methodological power in qualitative research", International Journal of Qualitative Studies in Education, 16 (2): 175-196.

REINHARZ S., 1992, Feminist Methods in Social Research, New York, Oxford University Press. 
SCOTT J., 1990, Domination and the Arts of Resistance: Hidden Transcripts, Yale, Yale University Press.

SHEPHERD L. J., 2008, "To Save Succeeding Generations from the Scourge of War': The US, UN, and the Violence of Security", Review of International Studies, 34 (2): 293-311.

SHEPHERD L. J., 2010, "Sex or Gender? Bodies in World Politics and Why Gender Matters", Gender Matters in Global Politics: A Feminist Introduction to International Relations, London, Routledge: 3-16.

TRUE J. and MINSTROM M., 2001, "Transnational Networks and Policy Diffusion: The Case of Gender Mainstreaming", International Studies Quarterly, 45 (1): 27-57.

UNSCR 1325 on Women, Peace and Security, S/Res/1325 (2000), Available online: http://www.un.org/events/res_1325e.pdf

UVIN P., 2001, "Reading the Rwandan genocide", International Studies Review, 3 (3): 75-99.

WASSERFALL R. R., 1997, "Reflexivity, Feminism and Difference”, in HERZ R. (ed), Reflexivity and Voice, Thousand Oaks, CA, Sage.

WIBBEN A.T., 2010, Feminist Security Studies. A narrative Approach, London, Routledge.

WILKINSON S., 1988, "The Role of Reflexivity in Feminist Psychology", Women's Studies International Forum, 11: 493-502.

\section{NANAN.N}

Maria Martín de Almagro Iniesta is Postdoctoral Researcher

in Political Science, Université Libre de Bruxelles

E-mail : mmartind@ulb.ac.be 